\title{
The brain decade in debate: VIII. Peptide hormones and behavior: cholecystokinin and prolactin
}

\author{
M.C. Beinfeld ${ }^{1}$, \\ J.C. Bittencourt², \\ R.S. Bridges ${ }^{3}$, \\ P.L. Faris ${ }^{4}$, \\ A.B. Lucion ${ }^{5}$, \\ A.G. Nasello6, \\ A. Weller ${ }^{7}$ and \\ L.F. Felicio ${ }^{8}$
}

\author{
${ }^{1}$ Department of Pharmacology and Experimental Therapeutics, \\ Tufts University School of Medicine, Boston, MA, USA \\ ${ }^{2}$ Departamento de Anatomia, Instituto de Ciências Biomédicas, \\ Universidade de São Paulo, São Paulo, SP, Brasil \\ ${ }^{3}$ Department of Biomedical Sciences, Tufts U niversity School of \\ Veterinary Medicine, North Grafton, MA, USA \\ ${ }^{4}$ Division of Neuroscience Research, MMC 392, Department of Psychiatry, \\ University of Minnesota, Medical School, Minneapolis, MN, USA \\ ${ }^{5}$ Departamento de Fisiologia, U niversidade Federal do Rio Grande do Sul, \\ Porto Alegre, RS, Brasil \\ ${ }^{6}$ Departamento de Ciências Fisiológicas, Faculdade de Ciências Médicas da \\ Santa Casa de São Paulo, São Paulo, SP, Brasil \\ ${ }^{7}$ Developmental Psychobiology Laboratory, Department of Psychology, \\ Bar Ilan University, Ramat, Gan, Israel \\ ${ }^{8}$ Departamento de Patologia, Faculdade de Medicina Veterinária e Zootecnia, \\ Universidade de São Paulo, São Paulo, SP, Brasil
}

\section{Correspondence \\ L.F. Felicio \\ Departamento de Patologia \\ Faculdade de Medicina \\ Veterinária e Zootecnia, USP \\ Av. Orlando Marques Paiva, 87 \\ 05508-900 São Paulo, SP \\ Brasil}

The names of the authors are presented in alphabetical order, except for the last one that corresponds to the symposium organizer.

Publication supported by FAPESP.

$\ldots \ldots \ldots \ldots \ldots \ldots$

Received August 8, 2001

Accepted August 27, 2001

\section{Abstract}

This article is a transcription of an electronic symposium held on November 28, 2000 in which active researchers were invited by the Brazilian Society of Neuroscience and Behavior (SBNeC) to discuss the advances of the last decade in the peptide field with particular focus on central actions of prolactin and cholecystokinin. The comments in this symposium reflect the diversity of prolactin and cholecystokinin research and demonstrate how the field has matured. Since both peptides play a role in reproductive behaviors, particularly motherinfant interactions, this was the starting point of the discussion. Recent findings on the role of the receptor subtypes as well as interaction with other peptides in this context were also discussed. Another issue discussed was the possible role of these peptides in dopamine-mediated rewarding systems. Both prolactin and cholecystokinin are involved in mechanisms controlling food intake and somatic pain thresholds. The role of peripheral inputs through vagal afferents modulating behavior was stressed. The advent of knockout animals as potential generators of new knowledge in this field was also addressed. Finally, interactions with other neuropeptides and investigation of the role of these peptides in other fields such as immunology were mentioned. Knowledge about the central functions of prolactin and cholecystokinin has shown important advances. The role of these peptides in neurological and psychiatric syndromes such as anorexia, drug abuse and physiological disturbances that lead to a compromised maternal behavior seems relevant.
Key words

- CCK

- PRL

- Dopamine

- Maternal behavior

- Bulimia

- Motivation 


\section{Introduction}

The versatility of peptide hormones is such that almost every peptide hormone is also a neuropeptide. It has been proposed that some of them may be neurotransmitters, although, in general, they act as neuromodulators. Actions of peptide hormones on the central nervous system are almost always related to their physiological functions at the periphery. Both peripheral and brain peptides are involved in behaviorally meaningful nervous system functions. This is particularly true for cholecystokinin and prolactin. These hormones induce satiety and facilitate maternal behavior, respectively. Nevertheless, a range of central cholecystokinin and prolactin effects has been described recently. Both cholecystokinin and prolactin are involved in dopaminergic transmission. The interrelations of the cholecystokinin and dopaminergic systems are responsible for the role of these peptides in several neurological and psychiatric syndromes such as Parkinson's disease, Huntington's chorea, schizophrenia, bulimia, anorexia and anxiety. Besides their interactions with the dopaminergic systems, there are important relations among prolactin, thyroid and gonadal hormones since prolactin regulates the physiological and pathological effects of these hormones. The relation between prolactin and stress is well known. In addition, both peptides have modulatory effects on each other's best-known central functions.

\section{From your results, which behavior(s) is being affected by a particular hormone? What is the systemic mechanism of it?}

Robert Bridges: My research focus that is relevant to this discussion pertains to the role of prolactin and placental lactogens in the central regulation of maternal behavior in mammals. We have found that infusions of prolactin or rat placental lactogen into the medial preoptic area of steroid-primed virgin female rats stimulate a rapid onset of maternal behavior (1-5). I am interested in how we want to proceed with our discussion of prolactin, cholecystokinin and behavior.

Aron Weller: My relevant research focuses on early, postnatal behavioral development in the rat, and the role of cholecystokinin in mediating various aspects: infantmother interaction, stress and comfort, natural and learned preferences, feeding, and satiety. Dear Dr. Bridges, if I recall correctly, your research on cholecystokinin and maternal behavior found that it acts as an antagonist of opiate inhibition, and that it affects maintenance, but not initiation of maternal behavior $(6,7)$. These findings, reported in your studies with Felicio, are a few years old. Is there an update? Is there a connection with prolactin? With humans?

Robert Bridges: Dr. Weller, we have not pursued these studies to any extent over the past few years. Rather, we have focused our efforts on the involvement of the prolactin receptor in regulating the onset of maternal behavior. Our most recent efforts have demonstrated that central (medial preoptic area, MPOA) infusions of the prolactin receptor antagonist, S179D-prolactin (5), delay the onset of maternal care in steroid-primed nulliparous rats. The interaction between prolactin and cholecystokinin certainly would be of interest to pursue.

Aron Weller: Dr. Bridges and Dr. Felicio, in a manner analogous to your studies on initiation and maintenance of maternal behavior, Dr. Raymond Nowak of CNRS, Tours, France, has been studying the role of cholecystokinin receptors in the development of preference for the mother ("bonding") in sheep, and we have been studying the role of cholecystokinin in infant-mother attraction/preference in rats (maintenance). We actually get a complicated pattern. Nowak (8) reports a blockade of bonding (preference toward the mother) by a CCK1 receptor antagonist, and a facilitation with a CCK2 
antagonist. We found increased preference rates toward aspects of the mother and nest induced by antagonists of both receptor types $(9,10)$. Dr. Felicio, Dr. Bridges said earlier that he hasn't followed up your findings on cholecystokinin and maternal behavior. Do you have any recent (last few years) findings in that area?

Luciano Felicio: Both CCK1 and CCK2 (previously named CCKA and CCKB) (11) receptor antagonists potentiate morphine inhibitory effects on ongoing maternal behavior. This is consistent with previous results that demonstrated antagonistic effects of cholecystokinin and beta-endorphin on this behavior. These results suggest that both subtypes of cholecystokinin receptors might be involved in this multiple peptidergic control of maternal behavior in lactating rats (12). In addition, we found that pretreatment with the CCK1 antagonist lorglumide during late pregnancy disrupts maternal behavior in rats (13).

Aldo Lucion: I have been studying the role of oxytocin in maternal aggressive behavior. Dr. Weller, do you think cholecystokinin would act directly on neurons or by means of stimulatory effects on oxytocin neurons, or maybe both?

Aron Weller: Dr. Lucion, that is simply too general a question. It depends on the particular circuit and/or behavioral system. I think virtually all possibilities exist: peripheral and central, CCK1 and CCK2, direct and mediated (by oxytocin, and more) options. In the case of satiety, it seems that both peripheral and central cholecystokinin receptors may be involved (14,15). I do not know if some of them activate an oxytocinergic circuit. Regarding most behaviors studied in infant rats, this is simply unknown, and as yet unstudied.

Aldo Lucion: Dr. Weller, very interesting results. Could you comment on cholecystokinin receptors in the central nervous system of infant rats? Are they expressed as in adults? And finally would there be an interaction of neonatal stress and cholecystokinin on bonding and mother-infant interaction?

Aron Weller: Dr. Lucion, regarding central cholecystokinin receptors: brain cholecystokinin receptors appear to have a primarily postnatal ontogeny. Studies of specific binding of cholecystokinin to rat forebrain and midbrain have shown an increase from birth, peaking around days 12-13, staying high until about day 17-20, followed then by a gradual decrease to adult levels in the fourth week of life. Simultaneously, the distribution of brain cholecystokinin receptors becomes gradually more extensive as the pup matures: cholecystokinin receptors are first found in the central cingulate and pyriform cortices on postnatal day 1 , confined to limbic areas up to day 10 , after which a rapid development is noted, approximating the adult's distribution by day 15 (16-18). Regarding cholecystokinin, stress, bonding and mother-infant interaction: an intriguing and promising field! Not much is known, let's study it!

Patricia Faris: Dr. Weller, I am very interested in making some sense out of CCK1 versus CCK2 antagonists. Our early data suggested the CCK1 receptor was involved in blocking opiate analgesias (19) but, as you know, Benoliel and Wiesenfeld-Hallin (2022) have presented evidence for the two receptors in this phenomenon. How do you interpret your finding that both are involved in your measure of infant-mother preference in rats?

Aron Weller: Dr. Faris, well, any interpretation I will give will be pretty speculative. There are several possibilities. Here is my favorite one: it is possible that the CCK1 receptors involved are part of circuits mediating the reward/incentive value of maternal cues, and that the CCK 2 circuit is an anxiety mediating one. That way, a similar effect could be produced by different pathways.

Margery Beinfeld: Dr. Weller, Hi! I like that idea. I think the dopamine reward sys- 
tem is doing a lot.

Aron Weller: Dr. Beinfeld, thanks, I also think that cholecystokinin, dopamine and reward systems have a future in infancy research and beyond.

Robert Bridges: Dr. Lucion, would you update us on the role of oxytocin in maternal aggression? Have you identified what neural region is mediating this response? I assume that oxytocin is stimulating maternal aggression, if it is involved in this behavioral response.

Aldo Lucion: Dr. Bridges, in fact, the stimulatory effect of oxytocin on maternal aggression was our hypothesis. However, it turned out that oxytocin injected into the medial amygdala and also into the BNST (bed nucleus stria terminalis) decreased maternal aggression in a dose-response manner (23-25).

Robert Bridges: Dr. Lucion, what mechanism do you think may underlie the actions of oxytocin on maternal aggression? Have you examined the involvement of the MPOA in this process?

Aldo Lucion: Dr. Bridges, the inhibitory effect of oxytocin on maternal aggression was very surprising for us. We have been thinking of the effect of oxytocin on GABAergic neurons in the amygdala but we have not yet studied this in the MPOA. Dr. Weller, could cholecystokinin be involved in apoptosis in the brain?

Aron Weller: Dr. Lucion, CCK may be involved in apoptosis. However, the data I am familiar with only relate to apoptosis in the pancreas, not the brain. CCK is a known peripheral trophic factor. Interestingly, both supraphysiological concentrations (26) and the lack of receptors (27) or withdrawal from high levels of CCK (28) have all been implicated in apoptosis in the pancreas.

Antonia G. Nasello: We have been working on prolactin at least for the last 15 years and on cholecystokinin at least for 7 years. We studied the effects of these two peptides on several behaviors and some mechanisms related to them (29-36).

Patricia Faris: We conduct both basic anatomical and behavioral studies in the rat and clinical trials in human subjects. The main focus of my laboratory is on vagal afferent modulation of higher central nervous system processes. As such, we are focused on the role of peripheral enteroendocrine cholecystokinin in food intake and modulation of somatic pain thresholds, a function modulated by vagal afferent activity. Specifically, we are interested in interactions between cholecystokinin, opiates, and serotonin. The clinical disorder we focus on is bulimia nervosa. For clinical implications, cholecystokinin ligands are likely to be novel treatments for modulating opioid analgesia, inhibiting some forms of unrestrained eating, and blocking panic attacks. The latter is marginal to my area of expertise (37-40).

Jackson Bittencourt: My assumption on this subject is that peptide hormones can participate in many brain functions, and this will depend mainly on the distribution of their receptors and the interactions with any given behavior should be related to the brain areas with the richest receptor innervation. My main flow of research is mapping by in situ hybridization, immunohistochemistry and neuronal tracer neuropeptides and/or hormones in the central nervous system of mammals (mainly as models the rat and monkey brains). I have helped to discover two neuropeptides in the mammalian brain, urocortin and melanin-concentrating hormone (41-45). Right now the scientific community has jumped on these two peptides and their relation to feeding behavior or, better yet, to energy balance control. Dr. Faris, it would be very interesting to see the interactions between cholecystokinin and urocortin in food intake since urocortin is expressed in the cells of the enteric nervous system, or at least in the cells in the wall of the gut.

Patricia Faris: Have you looked at the effects on food intake with urocortin in va- 
gotomized rats? Could you please briefly summarize the effects of urocortin on food intake? Does it affect a component of the meal or body weight with chronic administration?

Jackson Bittencourt: It seems clear that all mechanisms involved in the controls of any behavior are not entirely understood. In the case of urocortin, a new peptide member of the corticotropin-releasing factor (CRF) family, such kind of interactions should occur with the CRF receptors that urocortin has affinity for, mainly the CRF-R2 receptor. This receptor is distributed in subcortical fields, such as lateral septal nucleus and the ventromedial nucleus of the hypothalamus, and in the gut (46).

Antonia G. Nasello: Dr. Beifeld, in relation to cholecystokinin, dopamine and reward systems, we had some results with amphetamine and apomorphine-induced stereotyped behavior and cholecystokinin icv treatment and their antagonists peripherally administered. Cholecystokinin- 8 increased the amphetamine-induced stereotyped behavior and decreased the apomorphine-induced one. The tetrapeptide CCK4 had the same effect on amphetamine- but not on apomorphine-induced behavior (47). The results with CCK1 and CCK2 antagonists agreed with previous reports. Our results suggest that cholecystokinin has opposite influences on presynaptic and postsynaptic mechanisms. These results agree with previous ones obtained with specific antagonists for CCK1 and CCK2 receptors (34).

Margery Beinfeld: Dr. Nasello, it is clearly a complicated system and you may be right to propose that the influences could be pre- and postsynaptic. It would be interesting to try to do some mechanistic experiments. It is likely that modulation of dopamine release is involved, so that would be one approach.

Antonia G. Nasello: Dr. Beinfeld, since dopamine release is diminished in apomorphine-treated rats and dopamine release is increased in amphetamine-treated rats we are going to try to evaluate the cholecystokinin interaction with both drugs in perfusate obtained by microdialysis.

Margery Beinfeld: Dr. Nasello, good luck. I am sure it will be complicated. Another thing to consider is what is happening to cholecystokinin release with these treatments. It has now become possible to do these studies (although they are not easy) in awake rats and even mice. It is also possible that amphetamine causes some neurotoxicity, so perhaps cocaine might give a slightly different picture.

Antonia G. Nasello: Dr. Beinfeld, we agree with you but in our country it is very difficult to get cocaine for scientific purpose! It is really amazing!

Margery Beinfeld: Dr. Nasello, that is amazing. But you never know.

Antonia G. Nasello: Dr. Faris, can you explain to us the differences of cholecystokinin involvement in bulimia and nervous anorexia?

Patricia Faris: Dr. Nasello, cholecystokinin in anorexia versus bulimia. We have conceptualized these disorders as involving long-term energy balance abnormalities in anorexia, whereas bulimia patients are typically of normal body weight but do not feel full in response to a normal meal. Thus, this latter disorder could be considered a meal patterning disorder, a process known to be modulated by cholecystokinin. Recent evidence suggests that cholecystokinin may interact with long-term energy balance as evidenced by obesity in rats lacking the CCK1 receptor (48).

The role of cholecystokinin in anorexia is not very clear. This population is a difficult group to do mechanistic studies on, since they will not voluntarily consume enough diet to evoke cholecystokinin release. The results of blood levels are ambiguous. In bulimia, a clearer picture is emerging. Cholecystokinin release and ratings of satiety are blunted following a test meal in bulimia 
subjects. This appears to be secondary to delayed gastric emptying. We have hypothesized that vagal afferent tone is abnormal in bulimia nervosa, leading to alterations in the gastric accommodation relaxation, delayed gastric emptying, and blunted cholecystokinin and satiety. Clearly, the role of cholecystokinin in this disorder is an exciting area of research. Cholecystokinin stimulates oxytocin release in rats, both from the posterior pituitary and also in the dorsal medullarly nucleus of the solitary tract. This response has been suggested to be equivalent to the emetogenic response in vomiting animals, including humans.

Luciano Felicio: A curious aspect of both cholecystokinin and prolactin actions is that the acute and chronic behavioral effects are usually different and sometimes paradoxical. Recently, we have reported that sensitization to morphine can be induced by previous treatment with either CCK1 or CCK2 antagonists (49).

Antonia G. Nasello: Dr. Beinfeld, you have described tolerance for the effects of cholecystokinin (50). Can you make some comments about the possible mechanisms involved?

Margery Beinfeld: Dr. Nasello, tolerance usually means receptor internalization and the cholecystokinin receptor is certainly internalized but otherwise, I really don't know. One of the things that I have noticed is that the vast majority of work on the behavioral effects of cholecystokinin is done with agonists and antagonists with very little information about if and how much cholecystokinin is actually released by physiologically relevant stimuli. I know that it is not always possible to do that, but I think at least some of us should be thinking about that. We have started doing cholecystokinin microdialysis in awake freely moving rats and are getting some good results (51) but are planning to try to develop some better detection methods - perhaps using capillary zone electrophoresis.
Antonia G. Nasello: Dr. Beinfeld, it is the best approach and we wish you good luck.

Patricia Faris: Dr. Beinfeld, I agree totally with the need to measure levels of cholecystokinin. Also the knockouts that are devoid of cholecystokinin may be another approach independent of using antagonists. With regard to cholecystokinin, I am impressed by the emerging story on CCK 4 and panic disorder. Bradwejn and colleagues (5254) have provided an elegant series of experiments including receptor 2 polymorphisms in this patient population. Still the question of the origin of endogenous cholecystokinin for initiating a panic attack is unknown and, as mentioned by Dr. Beinfeld, levels of cholecystokinin need to be measured. Yet, a clear picture has emerged which strongly implicates cholecystokinin in the generation of panic episodes.

Margery Beinfeld: Dr. Bittencourt, I agree in general, but I am not sure density of innervation is the whole story. Some peptides (like cholecystokinin) are so abundant that even a little innervation might be enough to activate the receptors. We have started a breeding colony of cholecystokinin peptide receptor knockout mice and, the NIH willing, we will try to answer some questions. However, I worry a bit if the receptors seem to oppose themselves in many behaviors what the responses will be in the absence of the peptide. It is too bad the cholecystokinin receptor knockout mice are not more easily available.

Robert Bridges: Maybe this session could serve as a basis for a subsequent session on cholecystokinin, prolactin and behavior or common themes underlying the regulation of behaviors regulated by these peptides. Certainly prolactin is also involved in feeding in some species, including birds.

Patricia Faris: I would like to conclude by raising the possibility that some of the effects of oxytocin could occur through vagal afferents. I just wanted to make a last comment supporting the idea that peripheral 
inputs through vagal afferents modulate behavior as shown for learning and memory.

Antonia G. Nasello: Dr. Bridges, you have described that prolactin peaks during pregnancy and is significantly diminished after reproductive experience (55). In male rats we induced hyperprolactinemia using 60-day domperidone treatment and the increase of prolactin was higher in sexually experienced rats than in virgin rats (32). Apparently this is the opposite of what you have described for females after reproductive experience. Could you please give your opinion about these results?

Robert Bridges: Gladys, the alterations in prolactin secretion in reproductively experienced females may be the result of exposure to gonadal steroids and/or lactogenic hormones $(4,56)$. Perhaps, the males rendered hyperprolactinemic would display reduced prolactin levels if they were also primed with steroids. When did you sample the males relative to their state of hyperprolactinemia?

Antonia G. Nasello: Dr. Bridges, when we sampled the males, they were all of the same age, with the same treatment. The only difference was that a group was of virgin rats and the other was of experienced rats. We think that experienced rats were more exposed to endogenous steroids than the virgin ones.

Luciano Felicio: Both prolactin and cholecystokinin influence feeding and reproductive behaviors in various species. The multiple peptidergic control of such behaviors involves complex genetic mechanisms that generate and allow different strategies and degrees of success in competition. In addition to their complex peripheral central interaction, both peptides seem to play important roles in various immunological processes.

\section{Acknowledgments}

The authors and the SBNeC organizers are grateful to Dr. Claudio da Cunha for help with the organization of the chat. CNPq-Prossiga is also acknowledged for providing the chat room.

\section{References}

1. Bridges RS, Numan $M$, Ronsheim $P M$, Mann PE \& Lupini CE (1990). Central prolactin infusions stimulate maternal behavior in steroid-treated, nulliparous female rats. Proceedings of the National Academy of Sciences, USA, 87: 8003-8007.

2. Bridges RS, Robertson MC, Shiu RPC, Friesen HG, Stuer AM \& Mann PE (1996). Endocrine communication between conceptus and mother: placental lactogen stimulation of maternal behavior. Neuroendocrinology, 64: 57-64.

3. Bridges RS, Robertson MC, Shiu RP, Sturgis J D, Henriquez BM \& Mann PE (1997). Central lactogenic regulation of maternal behavior in rats: steroid dependence, hormonal specificity, and behavioral potencies of rat prolactin and rat placental lactogen I. Endocrinology, 138: 756-763.

4. Bridges RS, Henriquez BM, Sturgis JD \& Mann PE (1997). Reproductive experience reduces haloperidol-induced prolactin secretion in female rats. Neuroendocrinol- ogy, 66: 321-326.

5. Bridges RS, Rigero BA, Byrnes EM, Yang L \& Walker AM (2001). Central infusions of the recombinant human prolactin antagonist, S179D-PRL, delay the onset of maternal behavior in steroid-primed, nulliparous female rats. Endocrinology, 142: 730-739.

6. Felicio LF, Mann PE \& Bridges RS (1991). Intracerebroventricular cholecystokinin infusions block beta-endorphin-induced disruption of matemal behavior. Pharmacology, Biochemistry and Behavior, 39: 201204.

7. Mann PE, Felicio LF \& Bridges RS (1995). Investigation into the role of cholecystokinin in the induction and maintenance of maternal behavior in rats. Hormones and Behavior, 29: 392-406.

8. Nowak R, Goursaud AP, Levy F, Belzung $C$, Orgeur $P$, Schaal B, Picard M, MeunierSalaun MC, Alster P \& Uvnas-Moberg K (1997). Cholecystokinin receptors mediate the development of a preference for the mother by newly born lambs. Behavioral Neuroscience, 111: 1375-1382.

9. Shayit M \& Weller A (2001). Cholecystokinin receptor antagonists increase the rat pup's preference towards matemal-odor and rug texture. Developmental Psychobiology, 38: 164-173.

10. Weller A (2001). The ontogeny of motivation: Affective/hedonic preferences and their biological basis in developing rats. In: Blass EM (Editor), Handbook of Behavioral Neurobiology. Vol. 12. Plenum Press, New York (in press).

11. Alexander SPH \& Peters JA (1998). Receptor \& Ion Channel Nomenclature Supplement. Elsevier Trends J ournals, Cambridge, England, 26-27.

12. Miranda-Paiva CM \& Felicio LF (1999). Differential role of cholecystokinin receptor subtypes in opioid modulation of ongoing maternal behavior. Pharmacology, Biochemistry and Behavior, 64: 165-169.

13. Nasello AG, Felicio LF, Miranda-Paiva CM $\&$ Yin AJ (2001). Pretreatment with CCK $_{1}$ 
antagonist lorglumide induces inhibitory effects on ongoing maternal behavior of rats. J ournal of Molecular Neuroscience, 16 (Suppl): 73 (Abstract).

14. Gibbs J, Smith GP \& Geary N (1992). The brain-gut axis in the regulation of food intake. Regulatory Peptides (Letter), 4: 420.

15. Smith GP (2000). The controls of eating: brain meanings of food stimuli. In: Mayer EA \& Saper CB (Editors), Progress in Brain Research. Vol. 122. Elsevier Science Publisher B.V., Amsterdam, Netherlands, 173186.

16. Hays SE, Goodwin FK \& Paul SM (1981). Cholecystokinin receptors in brain: Effects of obesity, drug treatment and lesions. Peptides, 2: 21-26.

17. Pelaprat D, Dusart I \& Peschanski M (1988). Postnatal development of cholecystokinin (CCK) binding sites in the rat forebrain and midbrain: An autoradiographic study. Developmental Brain Research, 44: 119-132.

18. Robinson PH, Stephenson JD \& Moran TH (1993). Ontogeny of brain cholecystokinin receptors. In: Zagon IS \& M CLaughlin PJ (Editors), Receptors in the Developing Nervous System. Vol. 2. Neurotransmitters. Chapman \& Hall, Boca Raton, FL, USA.

19. Faris $\mathrm{PL}$, Beinfeld $M C$, Scallet $A C$, J ohannessen J N \& Olney JW (1986). Increase in hypothalamic cholecystokinin following acute and chronic morphine. Brain Research, 367: 405-407.

20. Bourgoin S, Benoliel JJ, Collin E, Mauborgne $A$, Pohl $M$, Hamon $M \&$ Cesselin $F$ (1994). Opioidergic control of the spinal release of neuropeptides. Possible significance for the analgesic effects of opioids. Fundamental and Clinical Pharmacology, 8: 307.

21. Becker C, Hamon M \& Benoliel JJ (1999). Prevention by 5-HT1A receptor agonists of restraint stress- and yohimbine-induced release of cholecystokinin in the frontal cortex of the freely moving rat. Neuropharmacology, 38: 525-532.

22. Wiesenfeld-Hallin Z, de Arauja Lucas G, Alster P, Xu XJ \& Hokfelt T (1999). Cholecystokinin/opioid interactions. Brain Research, 848: 78-89.

23. Giovenardi M, Padoin MJ, Cadore LP \& Lucion AB (1997). Hypothalamic paraventricular nucleus, oxytocin, and maternal aggression in rats. Annals of the New York Academy of Sciences, 807: 606-609.

24. De Almeida RM \& Lucion AB (1997). 8OH-DPAT in the median raphe, dorsal periaqueductal gray and corticomedial amyg- dala nucleus decreases, but in the medial septal area it can increase matemal aggressive behavior in rats. Psychopharmacology, 134: 392-400.

25. Giovenardi M, Padoin MJ, Cadore LP \& Lucion AB (1998). Hypothalamic paraventricular nucleus modulates maternal aggression in rats: effects of ibotenic acid lesion and oxytocin antisense. Physiology and Behavior, 63: 351-359.

26. Sata $\mathrm{N}$, Klonowski-Stumpe $\mathrm{H}$, Han B, Luthen R, Haussinger D \& Niederau C (1999). Supraphysiological concentrations of cerulein induce apoptosis in the rat pancreatic acinar cell line AR4-2J. Pancreas, 19: 76-82.

27. J imi A, Kojiro M, Miyasaka K, Kono A \& Funakoshi A (1997). Apoptosis in the pancreas of genetically diabetic rats with a disrupted cholecystokinin (CCK-A) receptor gene. Pancreas, 14: 109-112.

28. Oates PS, Morga RG \& Light AM (1986). Cell death (apoptosis) during pancreatic involution after raw soya flour feeding in the rat. American J ournal of Physiology, 250: G9-G14.

29. Felicio LF, Miranda WL \& Nasello AG (1988). Prolactin levels in male and female rats perinatally treated with bromopride. Brazilian J ournal of Medical and Biological Research, 21: 133-136.

30. Nasello AG \& Felicio LF (1990). Avoidance behavior, prolactin, HVA and DOPAC in offspring of bromopride treated rats. Pharmacology, Biochemistry and Behavior, 37: 571-575.

31. Nasello AG, Felicio LF \& Cisternas JR (1995). Interrelación dopamina-prolactinacomportamiento. Revista Argentina de Endocrinologia y Metabolismo, 32: 117124.

32. Nasello AG, Vanzeler MLA, Madureira EH \& Felicio LF (1997). Effects of acute and long-term domperidone treatment on prolactin and gonadal hormone levels and sexual behavior of male and female rats. Pharmacology, Biochemistry and Behavior, 58: 1089-1094.

33. Cruz-Casallas PE, Nasello AG, Hucke EETS \& Felicio LF (1999). Central prolactin dual modulation of male sexual behavior in rats: relationship with in vivo striatal dopaminergic activity. Psychoneuroendocrinology, 24: 681-693.

34. Tieppo CA, Ferreira FS, Sassatani AS, Felicio LF \& Nasello AG (2000). Differential modulation of apomorphine- or amphetamine-induced stereotyped behavior by $\mathrm{CCK}_{1}$ and $\mathrm{CCK}_{2}$ antagonists. European J ournal of Pharmacology, 387: 189-196.

35. Tieppo CA, Nasello AG \& Felicio LF
(1997). Modulation of apomorphine-induced stereotyped behavior by cholecystokinin. Progress in Neuro-Psychopharmacology and Biological Psychiatry, 21: 683695.

36. Tieppo CA, Silva AMP, Palermo-Neto J, Nasello AG \& Felicio LF (1995). Intracerebroventricular cholecystokinin infusions reduce stereotypy in dopamine-supersensitive rats. Brazilian J ournal of Medical and Biological Research, 28: 351-354.

37. Raymond NC, de Zwaan M, Faris PL, Nugent SM, Achard DM, Crosby RD \& Mitchell JE (1995). Pain thresholds in obese binge-eating disorder subjects. Biological Psychiatry, 37: 202-204.

38. Faris $\mathrm{PL}, \mathrm{Kim} \mathrm{SW}, \mathrm{Meller} \mathrm{WH}$, Goodale RL, Hofbauer RD, Oakman SA, Howard LA, Stevens ER, Eckert ED \& Hartman BK (1998). Effect of ondansetron, a 5-HT3 receptor antagonist, on the dynamic association between bulimic behaviors and pain thresholds. Pain, 77: 297-303.

39. Raymond NC, Eckert ED, Hamalainen M, Evanson D, Thuras PD, Hartman BK \& Faris PL (1999). A preliminary report on pain thresholds in bulimia nervosa during a bulimic episode. Comprehensive Psychiatry, 40: 229-233.

40. Faris PL, Kim SW, Meller WH, Goodale RL, Oakman SA, Hofbauer RD, Marshall AM, Daughters RS, Banerjee-Stevens D, Eckert ED \& Hartman BK (2000). Effect of decreasing afferent vagal activity with ondansetron on symptoms of bulimia nervosa: a randomised, double-blind trial. Lancet, 355: 792-797.

41. Bittencourt J C, Presse F, Arias C, Peto $C$ Vaughan J, Nahon J L, Vale W \& Sawchenko PE (1992). The melanin-concentrating hormone system of the rat brain: An immuno- and hybridization histochemical characterization. J ournal of Comparative Neurology, 319: 218-245.

42. Bittencourt J C, Vaughan J, Arias C, Rissman RA, Vale WW \& Sawchenko PE (1999). Urocortin expression in rat brain: evidence against a pervasive relationship of urocortin-containing projections with targets bearing type 2 CRF receptors. J ournal of Comparative Neurology, 415: 285-312.

43. Nahon J L, Presse F, Bittencourt J C, Sawchenko PE \& Vale W (1989). The rat melanin-concentrating hormone messenger ribonucleic acid encodes multiple putative neuropeptides coexpressed in the dorsolateral hypothalamus. Endocrinology, 125: 2056-2065.

44. Nahon J L, Presse F, Vaughan J, Fischer W, Bittencourt J C, Hoeger C, Schoepfer 
R, Rivier J, Sawchenko PE \& Vale W (1989). Characterization of mammalian melanin concentrating hormones and their precursors. In: Casanueva FF \& Diegez C (Editors), Recent Advances in Basic and Clinical Neuroendocrinology. Elsevier Science Publisher B.V., Amsterdam, Netherlands, 15-23.

45. Vaughan J, Donaldson C, Bittencourt J, Perin $\mathrm{MH}$, Lewis $\mathrm{K}$, Sutton $\mathrm{S}$, Chan $\mathrm{R}$, Tumbull AV, Lovejoy D, Rivier C, Rivier J , Sawchenko PE \& Vale W (1995). Urocortin, a mammalian neuropeptide related to fish urotensin I and to corticotropin-releasing factor. Nature, 378: 287-292.

46. Van Pett K, Viau V, Bittencourt J C, Chan RK, Li HY, Arias C, Prins GS, Perrin M, Vale W \& Sawchenko PE (2000). Distribution of mRNAs encoding CRF receptors in brain and pituitary of rat and mouse. J ournal of Comparative Neurology, 428: 191212.

47. Tieppo CA, Felicio LF \& Nasello AG (2001). Cholecystokinin modulation of apomorphine- or amphetamine-induced stereotypy in rats: opposite effects. Peptides, 22: 1291-1298.

48. Robinson PH, Stephenson J D \& Moran TH (1993). Ontogeny of brain cholecystokinin receptors. In: Zagon IS \& McLaughlin PJ (Editors), Receptors in the Developing Nervous System. Vol. 2. Neurotransmitters. Chapman \& Hall, Boca Raton, FL, USA.

49. Felicio LF, Mazzini BK, Cacheiro RC, Cruz TN \& Nasello AG (2001). Stimulation of either cholecystokinin receptor subtype reduces while antagonists potentiate or sensitize a morphine-induced excitatory response. Peptides, 22: 1299-1304.

50. Crawley J N \& Beinfeld MC (1983). Rapid development of tolerance to the behavioural actions of cholecystokinin. Nature, 302: 703-706.

51. Beinfeld MC \& Connolly K (2001). Activation of $\mathrm{CB} 1$ cannabinoid receptors in rat hippocampal slices inhibits potassiumevoked cholecystokinin release, a possible mechanism contributing to the spatial memory defects produced by cannab- inoids. Neuroscience Letters, 301: 69-71.

52. Moran TH (2000). Cholecystokinin and satiety: current perspectives. Nutrition, 16: 858-865.

53. Kennedy J L, Bradwejn J, Koszycki D, King N, Crowe R, Vincent J \& Fourie O (1999). Investigation of cholecystokinin system genes in panic disorder. Molecular Psychiatry, 4: 284-285.

54. Noble F, Wank SA, Crawley J N, Bradwejn $\mathrm{J}$, Seroogy KB, Hamon M \& Roques BP (1999). Intemational Union of Pharmacology. XXI. Structure, distribution, and functions of cholecystokinin receptors. Pharmacological Reviews, 51: 745-781.

55. Bridges RS, Felicio LF, Pellerin LJ , Stuer M \& Mann PE (1993). Prior parity reduces post-coital diumal and nocturnal prolactin surges in rats. Life Sciences, 53: 439-445.

56. Byrnes EM, Byrnes JJ \& Bridges RS (2001). Increased sensitivity of dopamine systems following reproductive experience in rats. Pharmacology, Biochemistry and Behavior, 68: 481-489. 